\title{
ASSESSMENT OF THE IMPACT OF VERMICOMPOST AND PEAT EXTRACTS ON NUTRIENT ACCUMULATION IN TUBERS AND POTATO YIELD
}

Lidija VOJEVODA, Institute of Agricultural Resources and Economics, Stende Research Centre, Dizzemes, Dizstende, Libagu parish, Talsu district Country: Latvia; lidija.vojevoda@arei.lv (corresponding author)

Anita OSVALDE, Institute of Biology, University of Latvia, Miera iela 3, Salaspils Country: Latvia; anita.osvalde@1lu.1v

Gunta ČEKSTERE, Institute of Biology, University of Latvia, Miera iela 3, Salaspils Country: Latvia; gunta.cekstere@1lu.lv Andis KARLSONS, Institute of Biology, University of Latvia, Miera iela 3, Salaspils Country: Latvia; andis.karlsons@1lu.lv

\begin{abstract}
Investigations on the potential beneficial effect of humic substances on crop plant cultivation under extremely diverse soil and climatic conditions is of global character, thereby knowledge obtained on the basis of local investigations are of great importance world-wide. The aim of the research was to evaluate the effect of different application methods (seed tuber treatment and foliar application) of commercially-produced peat and vermicompost extracts on nutrient uptake in tubers and yield of potato (Solanum tuberosum L.) using field experiments in organic farming system with potato variety 'Borodjanskij Rozovij'. The tested extracts from the organic products included: peat extract (K45) and vermicompost extract (B45) obtained at $+45^{\circ} \mathrm{C}$ by cavitation. The investigation was carried out at Stende Research Centre (Institute of Agro-resources and Economics) from 2011 to 2012. The chemical composition (N, P, K, Ca, Mg, $\mathrm{S}, \mathrm{Fe}, \mathrm{Mn}, \mathrm{Zn}, \mathrm{Cu}, \mathrm{Mo}, \mathrm{B}$ ) of potato tubers was determined. The application of organic extract from vermicompost had a stimulating effect on mineral nutrient as $\mathrm{N}, \mathrm{P}, \mathrm{K}, \mathrm{Mg}$, and $\mathrm{S}$ accumulation in potato tubers, but $50 \%$ of cases showed reduction in $\mathrm{Ca}$ and $\mathrm{Cu}$ content that could influence the storage of tubers. The use of peat extract was significantly effective when the tubers were treated before planting. On average, tuber treatment and foliar spray with organic extracts contributed to $10 \%$ of tuber yield increase.
\end{abstract}

Keywords: organic farming system, organic extracts, Solanum tuberosum L., chemical composition of tubers, yield.

\section{INTRODUCTION}

Potato (Solanum tuberosum L.) is one of the major bulbous crop and an important foodstuff in Latvia. With continuing consumer concerns related to food quality and safety, as well as the chemicals used in food production, the demand for organic products is gradually increasing all over the world (Gaurilcikiene et al., 2008). For organic potato producers one of the main challenges is nutrient management. This factor is limited by regulations prohibiting the use of chemical fertilisers, especially nitrogen (EU-regulation 2092/91). As increasing soil organic matter is a key aspect of organic production system, cover and green manure crops, composts, animal manure, and commercial organic fertilizers are typically used to ensure adequate nutrition for the potato production (Fawzy, 2010). An alternative possibility is related to the application of innovative means for plant nutrition and growth promotion. The ability of humic substances (HS) extracted from different plant-derived mineral-organic materials to stimulate growth and yield of numerous plants by increased seed germination, suppression of certain diseases, encouraged nutrient and water uptake is well documented (Theunisen et al., 2010; Chen et al., 2004; Nardi et al., 2002).

The use of peat substrates and vermicompost in agriculture is well known. They positively influence productivity of crops and enhance soil quality. Vermicompost contains essential nutrients in plant-available forms, enzymes, vitamins and plant growth hormones (Borah et al., 2007). Peat contains substances such as proteins and humic acids (Jun-zhang et al., 2004). Recently, there have been numerous trials on the use of humic substances as fertiliser (Klavins et al., 2004). Humic substances caused significant variation in the numbers of bacterial heterotrophs and autotrophic nitrifiers in the soil. Studies suggest that the mechanism through which humic acids affect both plant and soil microbes may chiefly involve enhancement of cell membrane permeability to nutrients (Valdrighi et al., 1996). Physiological effects of humic substances (HS) on the plant growth and metabolism depend on the source of (HS), concentration and molecular weight humic fraction (Nardi et al., 2002).

The aim of the research was to evaluate the effect of different application methods (seed tuber treatment and foliar application) of commercially-produced peat and vermicompost extracts on nutrient uptake in tubers and yield of potato (Solanum tuberosum L.) using field experiments in organic farming system.

Copyright (C) 2017 The Authors. Published by Aleksandras Stulginskis University. This is an open-access article distributed under the terms of the Creative Commons Attribution License (CC-BY 4.0), which permits unrestricted use, distribution, and reproduction in any medium, provided the original author and source are credited. 


\section{MATERIAL AND METHODS}

The investigation was carried out in organic cultivation systems at Stende Research Centre from 2011 to 2012. Meteorological conditions in 2011 and 2012 could be characterized with frequent precipitation and moderately warm summers.

The study was established in three replications with randomized treatment design. Early maturing potato variety 'Borodjanskij Rozovij' (the Ukraine) was chosen for the study. In organic cultivation system, the study was established on sod podzolic gleysolic soil with $\mathrm{pH} \mathrm{KCl}-6.5,3.8 \%$ organic matter, $1 \mathrm{M} \mathrm{HCl}$ extractable $\mathrm{P}-167 \mathrm{mg} \mathrm{L}^{-1}$ and $\mathrm{K}-125 \mathrm{mg} \mathrm{L}{ }^{-1}$ in 2011. Potatoes were planted by hand in the $3^{\text {rd }}$ decade of May. Spacing between tubers was $0.3 \mathrm{~m}$, row spacing $-0.70 \mathrm{~m}$.

During the vegetation period, the potato plantation was harrowed twice with a chain harrow - on $8^{\text {th }}$ and $14^{\text {th }}$ day after planting, and it was also loosened twice with a row-crop hoe RKT -2 on $7^{\text {th }}$ and $14^{\text {th }}$ day after planting.

In the organic cultivation system extracts from the organic products were applied corresponding to the following treatments:

1. control - untreated with extract of organic product;

2. tuber treatment with organic product extracts before planting;

3. plant treatment with organic product extracts three times in season: after germination, at plant height of $10 \mathrm{~cm}$ (grow stage (GS)18), before (GS 59) and after blooming stage (GS 69);

4. tuber treatment with organic product extracts before planting and plant treatment with these products three times in season in the above mentioned terms.

Tubers were treated with the extracts on the planting day using a back-pack sprayer JACTO HD 300, the dose of extracts was $150 \mathrm{~mL} \mathrm{t}^{-1}$, but the total spray material consumption was $5 \mathrm{~L} \mathrm{t}^{-1}$. The dose sprayed on the plants after sprouting of potatoes, before and after blooming was $1.5 \mathrm{~L} \mathrm{ha}^{-1}$. Extracts from organic products were sprayed with a special experimental bike-type sprayer Birchmeier Spray-Matic $10 \mathrm{~S}$. The sprayer is equipped with a flat jet nozzle with the pressure $250 \mathrm{kPa}$ and spray material consumption $-250 \mathrm{~L} \mathrm{ha}^{-1}$. Extracts of organic products were sprayed in the evening when the air temperature did not exceed $+20^{\circ} \mathrm{C}$.

Extracts from the organic products included: peat extract (K45) or elixir and vermicompost extract (B45) obtained at $+45^{\circ} \mathrm{C}$ by cavitation. Before application, the preparations were chemically analysed for nutrients. Results showed that extracts contain humic substances, macro - and microelements ( $\mathrm{N}, \mathrm{P}, \mathrm{K}, \mathrm{Mg}, \mathrm{Ca}, \mathrm{B}$, Mn, etc.) and microorganisms (Bremanis et al., 2013). The soil sample was taken befor potato planting. After the harvest, the nutrients in potato tubers were determined from the average sample of each treatment.

The chemical composition (N, P, K, Ca, Mg, S, Fe, Mn, Zn, Cu, Mo, B) of potato tubers was determined in the Laboratory of Plant Mineral Nutrition of the Institute of Biology of the University of Latvia. Dried and finely ground tuber samples were dry-ashed in concentrated $\mathrm{HNO}_{3}$ vapour and re-dissolved in $\mathrm{HCl}$ solution $(\mathrm{HCl}$ - distilled water mixture 3:100). The concentrations of $\mathrm{Ca}, \mathrm{Mg}, \mathrm{Fe}, \mathrm{Cu}, \mathrm{Zn}$, and $\mathrm{Mn}$ were measured by atomic absorption spectrophotometer (Perkin Elmer AAnalyst 700), those of N, P, Mo, B by colorimetry, S by turbidimetry (spectrophotometer JENWAY 6300), and K by flame photometry (Jenwey PFP7) (Rinkis et al., 1987).

\section{RESULTS AND DISCUSSIONS}

The concentrations of plant mineral nutrients were determined in soil prior to potato planting. In general, the content of nutrients: N, K, S, Zn, Cu, and B was very low in the soil (Nollendorfs et al., 2006) for optimal cultivation of potatoes corresponding to recommendations of Nollendorfs et al., 2006. The soil $\mathrm{pH} / \mathrm{KCl} 6.21$ was suitable for the potato cultivation.

The effect of organic product extracts on mineral nutrient content in the end product - potato tubers was estimated and found that, on the whole, peat and vermicompost extracts had an effect on macronutrient uptake by plants. In some cases, this effect was stimulative (Fig.1.). Several authors (Katkat et al., 2009; Kaushik and Garg, 2004) have also reported that humic substances have a stimulating effect on macronutrient $\mathrm{K}, \mathrm{N}, \mathrm{P}, \mathrm{Ca}$, and $\mathrm{Mg}$ uptake by plants.

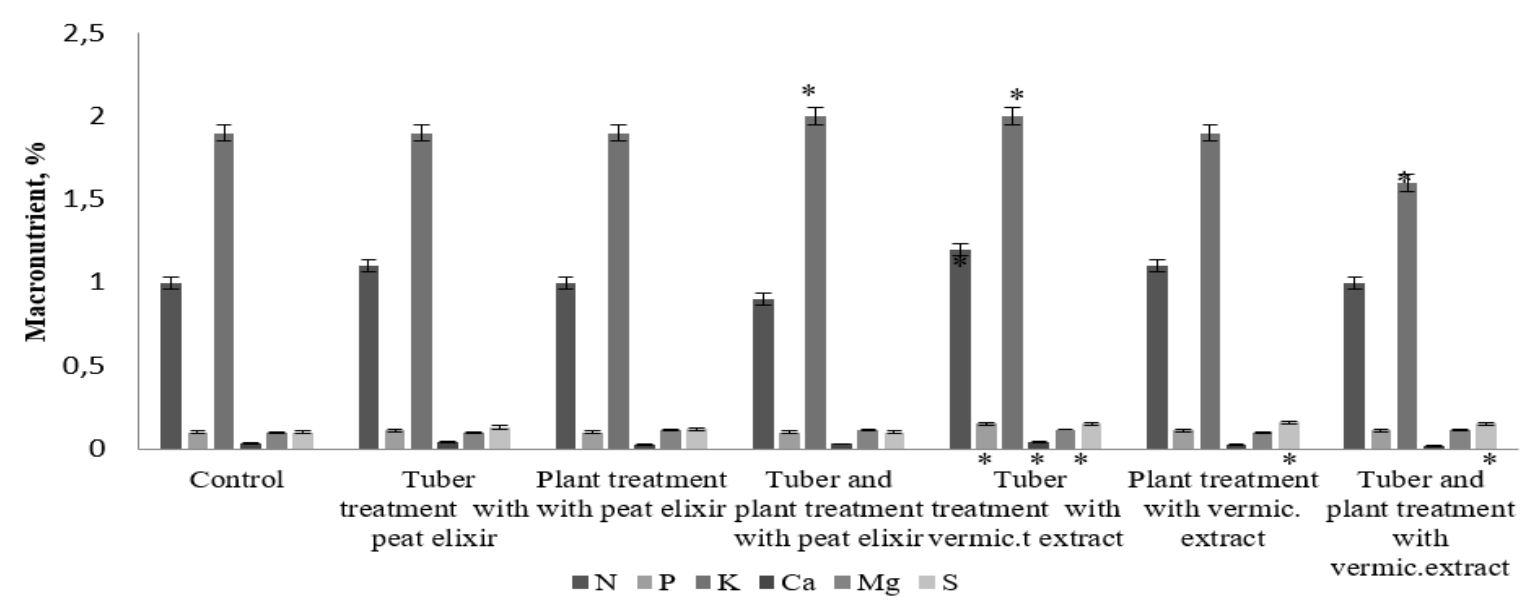

* - statistically significant differences from the control, $\mathrm{p}<0.05$

Figure 1. Macronutrient content in potato tubers, $\%$. 
Thus, vermicompost extract application increased all concentrations of macronutrient in potatoes.

The use of both extracts from peat and vermicompost contributed to Mg uptake, vermicompost extract increased potato also $\mathrm{S}$ concentrations in all treatments, while sprayings with vermicompost extract contributed to $\mathrm{N}$ and $\mathrm{P}$ accumulation. Nevertheless, in our investigation $50 \%$ of cases showed reduced Ca content in potato tubers, mainly in the treatments using foliar spray.

The use of almost all treatments of both extracts obtained from organic substances contributed to Mn and B uptake by potatoes, while only tuber treatment with vermicompost and peat extracts prior to planting delayed Cu accumulation in plants (Fig. 2). . However, many positive effects regarding the use of humic substances are reported in the scientific literature, some researchers have come to contrary conclusions according to which the obtained results highly depend on the concentration of the organic product extract (Ievinsch, 2011; Steinberg, 2003).

Estimation of the organic product extract effect on potato tuber yield in organic cultivation system leads to the conclusion that tuber treatment and foliar spray contributed to $10 \%$ yield increase on average (Fig. 3.).

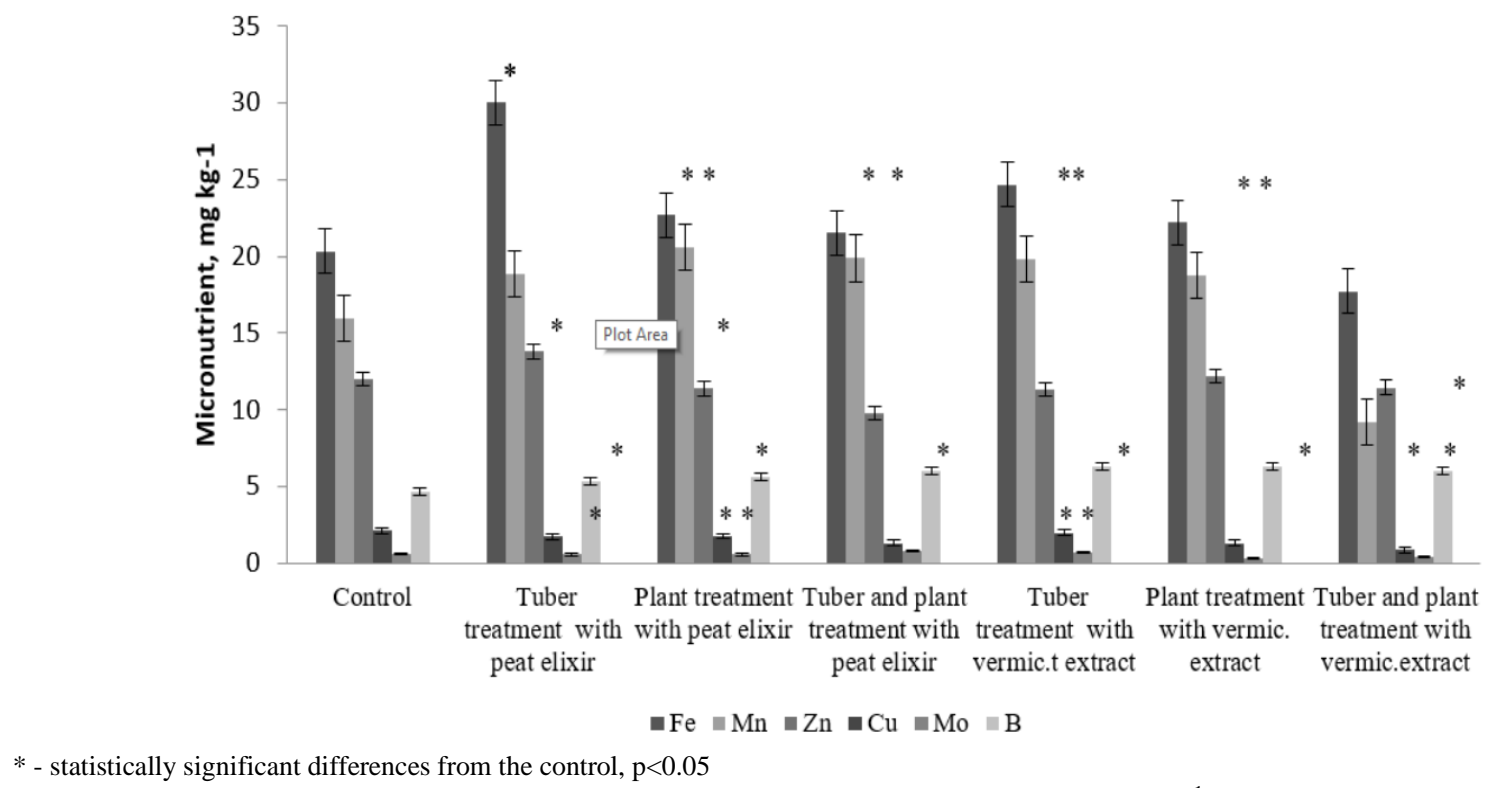

Figure 2. Micronutrient content in potato tubers, $\mathrm{mg} \mathrm{kg}^{-1}$

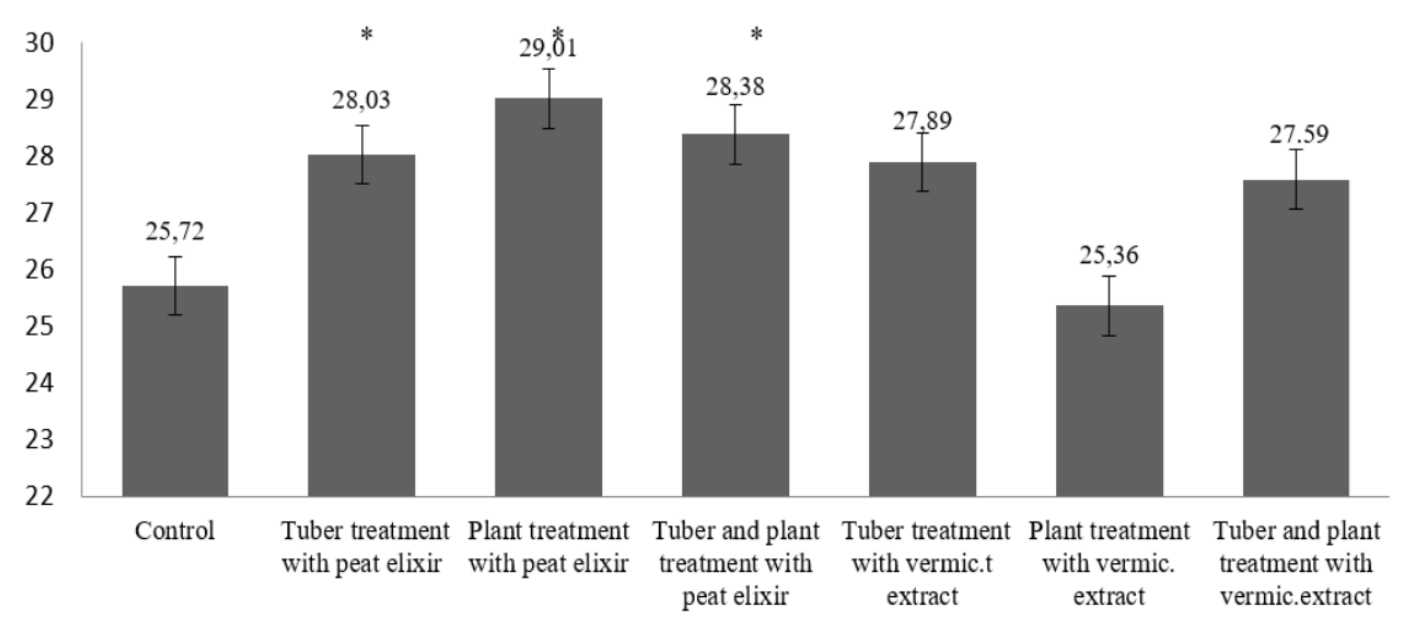

LSD $0.05=1.53, *$ - statistically significant differences from the control, $\mathrm{p}<0.05$

Figure 3. Potato tubers yield, $\mathrm{t} \mathrm{ha}^{-1}$

It should be noted that peat extract application was significantly $(\mathrm{p}<0.05)$ effective in all treatments. The estimated effect of organic extracts on the uptake of nutrients in potato in organic cultivation system was not only stimulating. Several positive and negative aspects should be noted. The potato leaf analyses suggest that peat and vermicompost preparations used in organic potato cultivation system enhanced $\mathrm{P}$ uptake but delayed $\mathrm{N}$ and $\mathrm{K}$ uptake by plants (Osvalde et al., 2016). Effect on micronutrient supply can also be different - applied organic extracts increased $\mathrm{Cu}$ and $\mathrm{B}$ content but decreased $\mathrm{Mn}$ and $\mathrm{Zn}$ content in the potato leaves. In most of cases applied peat and vermicompost extracts had a negative effect on $\mathrm{Zn}$ and Mo status of plants (Osvalde et al., 2016). These changes in nutrient status of potato leaves could have significant impact on tuber production.

However, treatments with organic extracts had a stimulating effect on various mineral nutrient accumulation in potato tubers, our study showed reduction in $\mathrm{Ca}$ and $\mathrm{Cu}$ content in $50 \%$ of cases that could influence the storage of tubers. During storage, 
the development of fungal diseases, such as tuber dry-rot of potato (casual agent Fusarium), Phoma dry-rot of potato tubers (casual agent Phoma exigua) (Turka and Bankina, 1999) were observed, but results were uncertain. Additional studies are necessary to carry out in order to reveal the possibility to control the mentioned diseases by utilizing products of organic origin and avoiding the use of chemical preparations used for plant protection, particularly in organic cultivation systems.

\section{CONCLUSIONS}

1. The application of organic extracts from vermicompost had significantly $(\mathrm{p}<0.05)$ a stimulating effect on mineral nutrient as $\mathrm{N}, \mathrm{P}, \mathrm{K}, \mathrm{Ca}, \mathrm{Mg}$, and $\mathrm{S}$ accumulation in potato tubers, but $50 \%$ of cases showed reduction in $\mathrm{Ca}$ and $\mathrm{Cu}$ content that could influence the storage of tubers.

2. On average, tuber treatment and foliar spray with organic extracts contributed to $10 \%$ of tuber yield increase. Peat extract application was significantly $(\mathrm{p}<0.05)$ effective for all treatments studied.

\section{ACKNOWLEDGEMENT}

This experiment was supported by ERAF project Nr. 2010/0313/2DP/2.1.1.10/10APIA/VIAA/082, and Vitols foundation.

\section{REFERENCES}

1. Borah, M. C., Mahanta, P., Kakoty, S. K., Saha, U. K., Sahasrabudhe, A. D. 2007. Study of quality parameters in vermicomposting. Journal Biotechnology, Vol. 6, pp. 410-413.

2. Bremanis, G., Klavins, M., Purmalis, O., Ziemelis, R .2013. Peat humic substances and Eartworm biohumus extracts for agricultural applications. Proceeding of The Latvian Academy of Scienses, Vol. 67, No. 3(684), pp. 20-30

3. Chen Y., Clapp C.E., Magen H. 2004. Mechanisms of plant growth stimulation by humic substances: the role of organic-iron complexes. Soil Science and Plant Nutrition, Vol. 50, pp.1089-1095. https://doi.org/10.1080/00380768.2004.10408579

4. Fawzy, Z.F. 2010. Increasing productivity of head lettuce by foliar spraying of some bio and organic compounds. Mesopotamia, Joyrnal Agric, No. 38, pp. 1-9.

5. Gaurilcikiene. I., Mankevičiene, A., Suproniene, S. 2011.The infestation of winter rye and triticale grain with Fusarium fungi as affected by fungicide use. Journal Žemdirbysté=Agriculture, Vol.98, No. 1, pp.19-26.

6. Ievinch G. 2011. Vermicompost treatment differentially affects seed germination, seedling growth and physiological status of vegetable crop species. Plant Growth Regulution, Vol.65, pp. 169-181. https://doi.org/10.1007/s10725-011-9586-X

7. Jun-zhang, L., Sen, L., Xiang-hua, Y. 2004. Application of peat to agriculture. Conservation. Util. Min. Research., Vol. 3, pp. $1135-1141$.

8. Katkat BB, Çelik H, Turan MA, Aşik BB. 2009. Effects of soil and foliar applications of humic substances on dry weight and mineral nutrients uptake of wheat under calcareous soil conditions. Journal of Basic \& Applied Sciences, Vol. 3, pp. 1266-1273.

9. Kaushik, P., Garg, V. K. 2004. Dynamics of biological and chemical parametrs duringvermikomposting of solid textile mill sludge mixed with cow dung and agricultural residues. Bioresource Technology, No. 94(2), pp. 203-209. https://doi.org/10.1016/j.biortech.2003.10.033

10. Klavins, M., Šìre, J., Eglīte, L. 2004. Humic substances and the potential of their use in agriculture. Proceedings of the Latvian Academy of Sciences, Vol. 58(2), pp. 39-49.

11. Nardi, S., Pizzeghello, D., Muscolo, A., Vianello, A. 2002. Physiological effects of humic substances on higher plants. Journal Soil Biology and Biochemistry, Vol. 34 (11), pp.1527-1536. https://doi.org/10.1016/S0038-0717(02)00174-8

12. Nollendorfs, V., Osvalde, A., Paegle, G. 2006. Barības elementu deficīta noteikšana kartupeļiem. Saimnieks, No. 6, pp. 18-21.

13. Osvalde, A., Karlsons, A., Cekstere, G., Vojevode, L. 2016. The effect of vermicompost-derived humic substances on nutrient status and yield of organic potato in field conditions. Acta Horticulturae. Vol. 1142, pp. 277-283. https://doi.org/10.17660/ActaHortic.2016.1142.42

14. Rinkis, G., Ramane, H., and Kunicka, T. 1987. Methods of soil and plant analysis. Riga, Latvia: Zinatne, pp.174.

15. Steinberg, E.W. 2003. Ecology of humic substances ion frescgwaters. Berlin: Springer- Verlag Heidelberg, pp. 95.

16. Theunissen, J., Ndakidemi, P.A., Laubscher, C.P. 2010. Potential of vermicompost produced from plant waste on the growth and nutrient status in vegetable production. International Journal of the Physical Sciences, Vol. 5(13). pp. 1964-1973.

17. Turka, I., Bankina, B.1999. Kartupeļu lakstu puves Phytopthora infestans apkarošana Latvijā. Agronomijas vēstis, Nr.1, LLMZA, LU, pp. 94-100. [In Latvian]

18. Valdrighi, M. M., Pera, A., Agnolucci, M., Frassinetti S., Lunardi, D.,Vallini, G. 1996. Effects of compost-derived humic acids on vegetable biomass production and microbial growth within a plant (Cichorium intybus)-soil system: A comparative study. Agricultural Ecosystem, No. 58(2-3), pp.133-144. https://doi.org/10.1016/0167-8809(96)01031-6 